\title{
Trends of Integrated Support of Vocational Training and Career Development among People with Disorders of the Musculoskeletal System: The Essence and Main Determinants
}

\author{
Vagif Deirushevich Bairamov ${ }^{1}$ \\ Dmitry Sergeevich Raidugin ${ }^{2}$ \\ Nikita Andreevich Vyalykh ${ }^{3}$ \\ ${ }^{1}$ Moscow State University of Humanities and Economics, Moscow, Russian Federation \\ ${ }^{2}$ Moscow State University of Humanities and Economics, Moscow, Russian Federation \\ ${ }^{3}$ Southern Federal University, Rostov-on-Don, Russian Federation \\ Email: info@mggeu.ru
}

\section{Doi:10.5901/mjss.2015.v6n4s4p34}

\section{Abstract}

The article discusses an important and urgent problem of providing integrated support for vocational training and career development of disabled people and persons with musculoskeletal disorders (MSD). Thus, under the complex support training and career development, the authors define a set of measures to improve the efficiency of these processes in individuals with MSDs disorders. The article shows that in the development of an integrated model of vocational training support for persons with MSD disorders should be considered, on the one hand, the functional purpose of the vocational training and career development, and on the other hand, the totality of the typical problems associated with disabilities. In addition, the concept of comprehensive support training and career development of persons with MSD disorders should take into account current socioeconomic realities.

Keywords: vocational training, career development, musculoskeletal system disorder, limited capacity, disability, comprehensive model of vocational training, humanism, inclusive strategy, segregation strategy.

\section{Introduction}

The inclusive education strategy and career development of people with disabilities today as a basis for social policy at all levels assumes an attitude to human life and individual freedom as the supreme value. The ideas of humanism and allround development of the personality of people with special needs is closely related to comprehensive model of vocational training and employment of persons with disabilities, designed to take into account the needs and characteristics of this category of persons by removing various barriers (both spatial and socio-cultural).

The consequence of the gradual humanization of social policy for people with special needs has become the Convention on the Rights of Persons with Disabilities, adopted by the UN General Assembly in 2006 and nowadays, together with its Optional Protocol, is the main international document regulating social policy for people with disabilities in all countries where it has been ratified. The latter include Russia as well. Without going into all the details of the document, some of which are not essential here, let us draw the attention to the excerpt from Article 8 devoted to educative work: "1. States Parties undertake to adopt immediate, effective and appropriate measures in order: a) to raise awareness throughout society, including at the family level, regarding persons with disabilities and to foster respect for the rights and dignity of persons with disabilities; b) to combat stereotypes, prejudices and harmful practices relating to persons with disabilities, including those based on sex and age, in all areas of life; c) to promote the capabilities and contributions of persons with disabilities" (UN Convention on the Rights of Persons with Disabilities, 2006). It is obvious that the accepted by Russia obligations listed in the above fragment: public awareness, fighting prejudice and stereotypes, develop the potential of persons with disabilities, etc., assume a detailed scientific study of the disability issue. 


\section{Literature Review}

Conceptual problems, associated with the specifics of teaching children with disabilities, have been studied by researchers such as Ramon and Schmidt (2003). Such scientists like Bunch (2008), Malofeev (1997), and larskaiaSmirnova (1999) developed the concept of integrated and inclusive education in their writings.

In our work, we rely on the idea of report by Kutepova (2014) - "Children with health limitations in the modern educational system: segregation, integration, inclusion" who wrote about the fact that, historically, there were three basic models of education of persons with health limitations: segregation (based on the separation of the environment of people with health limitations from the environment of persons without disabilities), integrative (partial fusion) and inclusive (full fusion).

Also, the represented views of Korobov are important in our study, who talks about the formation of foundations of a new social paradigm -"single community, including people with various problems" (Korobov, 2001) that assumes social and professional integration of persons with disabilities.

\section{Results and Discussion}

Addressing the issue of vocational training of people with health limitations, we should note, first of all, that along with the traditional process of education activities and requirements, such training implies a number of conditions related to the satisfaction of the special needs in the infrastructure, health, social, socio-psychological, legal, economic, and other significant aspects. Unfortunately, in modern Russia, according to various estimates, only slightly more than thirty universities (Decree of the President of the Russian Federation dated 05.07.2012), which is about 3\% of all Russian high schools (Order of the Ministry of Education of the Russian Federation dated 30.12.2010), are fully or partially equipped with infrastructural facilities allowing educating people with special needs. This narrows the opportunities of professional self-determination of people with disabilities considerably. With account of the total number of persons with health limitations in our country, which is about 13 million people, it becomes obvious that the Russian education system today is not able to provide this segment with educational services in full. This situation forces us to recognize that vocational training of people with health limitations is a rather complex social problem.

It is compounded by the fact that even the equipment of educational institutions with a barrier-free infrastructure is not the only condition for the effective support of professional education of persons with physical disabilities: the presence of elevators, ramps and handrails at the university or other institution does not guarantee that people with disabilities would feel comfortable enough not to be distracted from their studies or work to solve the mass of daily problems associated with their illnesses. Support of professional education of persons with health limitations includes a number of aspects that are interrelated with each other by the problem itself. The decision of this problem involves the creation of favorable conditions for training and professional fulfillment of persons with special needs by providing in addition to along the barrier-free physical space, also: adequate medical care; a legal framework and economic conditions accounting for the needs of people with health limitations; special teaching methods; psychological support; consideration of a number of other factors. That is why this problem is usually referred to as the problem of comprehensive support of professional education and employment of individuals with health limitations. The complex nature of support is determined by the fact that its implementation takes place in different areas: legal, economic, educational, socio-structural, socio-cultural, healthrelated, and others. However, all support measures should not just be aimed at a common goal of providing an accessible environment for people with disabilities. An indispensable condition for the effectiveness of these measures should also be their systematic, complete coordination, and subordination to the same principles.

As Kutepova (2014) noted in her report "Children with health limitations in the modern educational system: segregation, integration, inclusion," historically, there were three basic models of education of persons with health limitations: segregation (based on the separation of the environment of persons with health limitations from the environment of persons without disabilities), integrative (partial fusion) and inclusive (full fusion). Without going into the details of the report, we tend to agree with the proposed classification: in fact, if we take the degree of involvement of persons with health limitations in the social environment as a basis for the classification, then there is no alternative to the three listed above options.

The essence of the segregation strategy is to separate people with health limitations from ordinary people in the education process. According to this model, the training of people with health limitations should take place in specialized educational institutions, for example at universities and boarding schools. The same applies to employment: people with special needs are supposed to have a work at specially equipped premises, and with other conditions.

The integrative model suggests mutual adaptation of the individual and society to each other. Thus, it is a process, 
by which the individual adapts to the community, and, on the other hand, the community takes the necessary steps to adapt to this individual. According to Kutepova, the following features are typical of the integrative model: creation of compensatory groups at educational combined institutions, special (remedial) classes in secondary school, or the integration of individual children with disabilities in the circle of peers without disabilities. This model is widely used in the modern Russian education system.

However, the third model, called inclusive, seems to us the most adequate to modern social realities. The essence of inclusive education is reduced to the full inclusion of individuals with disabilities in the social environment of ordinary people. This approach involves learning together in the same group of mixed students - with and without disabilities. Career development in terms of inclusion also implies full inclusion of professionals with disabilities in a professional context, i.e. without any career restrictions.

Thus, one of the strategic objectives of the scientific community today is to develop an efficient algorithm for complex support of education processes and employment of people with disabilities. That is the purpose of this project, within the framework of which this article has been prepared.

By professional education, we mean a set of measures of educational and raising nature aimed to form competence in specific areas of vocational training, enabling a person with health limitations to implement further career development, i.e. to work successfully within the framework of the mastered profession, by both acquiring new professional skills, and perfecting the ones acquired in the course of vocational training.

A more precise definition can be obtained by comparing these two concepts. So, there is a number of important similarities, the main of which are:

Firstly, their relationship is reflected in the required stage-by-stage approach, where the primary stage is artistic training, and the subsequent stage is the career development. This connection lies in the fact that these two stages are not considered without each other: training is carried out for further career development, which, in turn, supported by the basic knowledge acquired in the course of vocational training.

Secondly, elements of learning are retained at both stages: both professional education and career development throughout the work assume constant development of the competences required for work and allowing a person with MSD to reach new professional levels, due to which, in fact, the development is provided. A refusal to acquire new job skills leads to professional stagnation and, in some cases, degradation and eliminates the prospects for career development.

Despite the close relation between these two concepts, a number of significant differences between them should be considered:

Firstly, the processes of training and career development are carried out in different social institutions: while an education institution is a base for vocational training, where a trainee acts as a student, career development always takes place at practice-oriented institutions; whether these are political, economic, or other institutes. However, career development can take place at an education institute, but the actor acts in this process as an employee, not as a student. Anyhow, the main point of the difference comes down to the fact that in the course of vocational training there are no practical requirements to the activities of the person and his performance is primarily evaluated based on well-established pedagogical forms, while the process of progressive career development is possible only in case of the practical effectiveness of the person's activity. In the phenomenological perspective, this distinction is that if the training needed remains necessary during the employee's career development, this factor becomes secondary, and the employer is primarily interested in the benefits the employee brings, rather than in his professional self-development.

The second major difference can be seen through the activity-based approach: if the professional education and career development are considered as interrelated processes that are gradually carried out in various social institutions, then it becomes evident that there is another stage, which serves as the demarcation line between them: it is the stage of employment. The need for employment occurs after the end of training and, in the case of successful overcoming of this phase, employment is the beginning of the next step-the career development. This fact may seem insignificant because of its obviousness, but it cannot be overlooked when developing a model of integrated support and career development of people with health limitations.

Another basic category is "comprehensive support." Comprehensive support of vocational training and career development means a set of measures to improve the efficiency of these processes in relation to persons with disorders of the musculoskeletal system. Developing the model of comprehensive support, we should take into account, on the one hand, the functional purpose of vocational training and career development of persons with disorders of the musculoskeletal system, on the other hand, the totality of typical problems associated with the disabilities.

Comprehensive support should be considered as a component of a complex multidisciplinary rehabilitation process of people with disorders of MSD in two perspectives: systemic and procedural. 
As a system of integrated support, professional education, and career development of disabled people, it consists of the following characteristics:

- it is an organized control system that includes: goals, objectives, activity principles and directions, forms and methods of implementation and the criteria for their performance, and other strategic and structure-forming elements;

- this system is primarily social in nature and its ultimate goal is to overcome the main problems related to labor integration of persons with disabilities;

- this system acts as a subsystem within the society systems (in respect to it), defining and implementing social policies of the state in respect of people with MSD (the education, legal, and political systems);

- in addition to unique components, it combines elements of other social systems, integrating first with the system of social protection of disabled persons;

- as a complex open system, integrated support of vocational training and career development of persons with MSD is exposed to the influence of external social environment.

Treating the comprehensive support as an additional element that is involved stage-by-stage in the processes of professional socialization of persons with disorders of the musculoskeletal system, in its simplest form it can be represented in the scheme: "professional education + comprehensive support - employment + comprehensive support career development + comprehensive support." Regardless of the stage, comprehensive support should be carried out in the following directions:

- adaptation of persons with disabilities to the requirements and standards of the society;

- improvement of employability, the personal and social status of persons with disabilities;

- implementation of multi-level and multi-dimensional measures of social adaptation of individuals with disabilities to the conditions of the surrounding society.

\section{Conclusions}

Today the system of vocational rehabilitation of persons with health limitations is at the difficult conceptual and practical stage of its formation. This period is associated with socio-economic restructuring of the state, changes in the value orientations of the Russian society, transformation of the public policy and society's attitudes towards persons with health limitations. Perhaps, we can say that now the foundations of a new social paradigm of a "single community including people with various problems" (Korobov, 2001), which assumes integrating disabled people in social and professional relations. Of course, the concept of the integrated support training and career development of persons with MSD should take into account current socio-economic realities. These macro-properties include: firstly, the active transition of socioeconomic activities to the market form, which reduces the extent of state control over the process of rehabilitation and highlights the social and personal components; secondly, the accelerating pace of daily life, forcing each of us to make every effort in order to remain in a social context, not to become obsolete and not to be left behind; thirdly (and this is a kind of a meta social characteristic), the active processes of social transformation in all spheres of life, which implies flexibility and openness of any system, seeking success. The system of comprehensive support of vocational training and career development of people with disorders of the musculoskeletal system, which must necessarily take into account all modern social requirements to such systems, is not an exception from the rule.

\section{Acknowledgement}

The material was developed in the framework of implementation of the basic part of the state task of the Ministry of Education and Science of the Russian Federation No. 2014/116 "Projective model of integrated support and career development of people with disorders of the musculoskeletal system."

\section{References}

Bunch, G. (2008). Podderzhka uchenikov s narusheniem intellekta v usloviiakh obychnogo klassa: posobie dlia uchitelei [Support for students with intellectual disabilities in a regular classroom. Manual for teachers]. Regional Public Organization of Disabled People "Perspective," Moscow [in Russian].

Iarskaia-Smirnova, E.R. (1999). Sotsial'no-psikhologicheskie osobennosti vzaimootnoshenii invalidov i zdorovykh [Socio-psychological characteristics of persons with disabilities and healthy people]. Sotsiologicheskie issledovaniia - Sociological researches, 4, 3845 [in Russian]. 
Konventsiia o pravakh invalidov: priniata rezoliutsiei General'noi Assamblei Organizatsii Ob"edinennykh natsii 13.12.2006 [Convention on the Rights of Persons with Disabilities: adoption of a resolution by the General Assembly of the United Nations of 13.12.2006]. Retrieved 21.06.2014 from http://www.un.org/ru/documents/decl_conv/conventions/disability.shtml [in Russian].

Korobov, M.V. (2001). Aktual'nye voprosy stanovleniia i razvitiia reabilitologii. [Topical issues of formation and development of Rehabilitation]. Mediko-sotsial'naia ekspertiza i reabilitatsiia invalidov: sb. nauchnykh trudov SPbIUVEK - Medical- examination and rehabilitation of disabled persons: Collection of scientific papers, 7, 9-21 [in Russian].

Kutepova, E.N. Deti s ogranichennymi vozmozhnostiami zdorov'ia v sovremennoi sisteme obrazovaniia: segregatsiia, integratsiia, inkliuziia [Children with health limitations in the modern educational system: segregation, integration, inclusion]. Retrieved 18.06.2014 from http://www.inclusive-edu.ru/

Malofeev, H.H. (1997). Sovremennyi etap v razvitii sistemy spetsial'nogo obrazovaniia v Rossii: rezul'taty issledovaniia kakosnova dlia postroeniia programmy razvitia [The current stage in the development of special education in Russia. The result of the study as a basis for building a development program]. Defektologiia - Defectology, 4, 3-15 [in Russian].

Prikaz Minobrnauki RF ot 30.12.2010 № 2211 «O bazovykh obrazovatel'nykh uchrezhdeniiakh vysshego professional'nogo obrazovaniia, obespechivaiushchikh usloviia dlia obucheniia invalidov $\mathrm{i}$ lits s ogranichennymi vozmozhnostiami zdorov'ia» [Order of the Ministry of Education of the Russian Federation № 2211 "About the basic educational institutions of higher education, providing conditions for training of disabled persons and with disabilities and persons with disabilities" of 30.12.2010]. [in Russian].

Ramon S., \& Schmidt, B. (2003). Social Exclusion and social. Moscow School of Social and Economic Sciences. Readings for the course Social exclusion in education.

Ukaz Prezidenta Rossiiskoi Federatsii ot 07.05.2012 № 599 «O merakh po realizatsii gosudarstvennoi politiki v oblasti obrazovaniia i nauki» [Decree of the President of the Russian Federation \#599 "On measures to implement the state policy in the field of education and science" of May 7, 2012]. [in Russian]. 